\title{
Model Latihan Motorik Halus Melalui Aquatic Introduction To Cooperative Game Anak Usia Dini
}

\author{
Hariadi $^{1}$, Suryansah ${ }^{2}$, M. Sururuddin ${ }^{3}$, Yul Alfian Hadi ${ }^{4}$, Suhirman ${ }^{5}$ \\ Universitas Hamzanwadi 1,2,3,4,5 \\ Email: hariadi@hamzanwadi.ac.id ${ }^{1}$, suryansah@hamzanwadi.ac.id ${ }^{2}$, \\ sururuddin@hamzanwadi.ac.id ${ }^{3}$,yulhadi7@,gmail.com ${ }^{4}$, suhirman.sakti@gmail.com $^{5}$
}

\begin{abstract}
Abstrak
Dalam penelitian ini bertujuan untuk mengetahui ada atau tidak hubungan Game Anak Usia Dini terhadap latihan motorik halus melalui akuatik introduction to cooperative Jenis Penelitian ini merupakan penelitian Deskriptif Kuantitatif. adalah metode tesperbuatan. Populasi penelitian ini adalah siswa R.A. Al-Irsyad Nw Kuang Derek Rumbuk yang memiliki siswa sebanyak 10 siswa pada kelas B sekaligus sampel, Teknik pengumpulan data menggunakan tes perbuatan dengan pre-test sebelum diberikan perlakuan,dan post-test setelah diberikan perlakuan. Data dianalisis menggunakan uji-t sebagai uji hipotesis penelitian. Hasil pada saat lemparan pertama kelompok A hanya mampu memmasukkan bola plastic ke dalam keranjang sebanyak $5 \%$ dan kelompok B sebanyak 4. 5\%. Kemudian pada lemparan ke dua kelompok A sebanyak $7 \%$ dan Kelompok B sebanyak 10 \%. Pada kesempatan kedua kelompok A disuruh untuk mengangkat dan menyebut huruf yang dipegang, semua peserta mengenal huruf dan bisa menyebut huruf yang dipegang hal yang sama juga dilakukan pada kelompok B. Namun pada kelompok B hanya satu peserta yang belum bisa menyebut huruf namun sudah mengenal huruf yang ditunjukkan. Kalau dipersentasekan dari kesempatan pertama kelompok A yang sudah mengenal huruf sebanyak $20 \%$ dan kelompok B sebanyak 10\% sedangkan yang belum bisa mengenal huruf dari kelompok A sebanyak 30\% dan kelompok B sebanyak 40\%. Setelah diberikan kesempatan kedua kelompok A yang sudah bisa menyebut dan mengenal angka sebanyak $100 \%$ dan pada kelompok B Sebanyak 90\%. sehingga dapat di simpulkan bahwa ada hubungan Latihan Motorik Halus Melalui Akuatik Introduction To Cooperative dan Game Anak Usia Dini.
\end{abstract}

Kata kunci: Motorik Halus; akuatik Introduction To Coperative Game; Anak Usia Dini

\begin{abstract}
In this study, the aim of this research is to see whether or not early childhood games are related to fine motor training through aquatics. Introduction to cooperatives. This type of research is a quantitative descriptive study. is a test-made method. The population of this study were students of R.A. Al-Irsyad Nw Kuang Derek Rumbuk which has 10 students in class $B$ at once, the technique and data use the action test with pre-test before being given treatment, and post-test after being given treatment. Data were analyzed using t-test as a test of the research hypothesis. The results at the time of the first throw of group A were only able to put the plastic ball into the basket by 5\% and group $B$ by $4.5 \%$. Then on the throw to the two groups $A$ as much as $7 \%$ and Group B as much as 10\%. On the second occasion group $A$ was asked to raise and mention the letter that was held, all participants recognized the letter and could say the letter that was held, the same thing was done in group B. showed. As a percentage, from the first opportunity, group $A$ who were familiar with letters was $20 \%$ and group $B$ was $10 \%$, while those who could not recognize letters from group A were $30 \%$ and group B was $40 \%$. After being given the opportunity, both group A were able to say and
\end{abstract}

Model Latihan Motorik (Hariadi, SUryansah, Sururuddin, Hadi,Suhirma) 387 
recognize numbers as much as $100 \%$ and group B as much as $90 \%$. So that it can be concluded that there is a relationship between Fine Motoric Training through Aquatics, Introduction to Cooperatives and Early Childhood Games.

Keywords: Fine Motor; aquatic Cooperative Game Introduction; Early childhood

\section{PENDAHULUAN}

Pendidikan merupakan salah satu hal yang menjadi kebutuhan hidup, bahkan menjadi hal yang wajib harus dilakukan oleh setiap insan untuk mendapatkan ilmu pengetahuan. Melalui ilmu pengetahuan permasalahan tentang kehidupan akan ditemukan bahkan sampai mengetahui jati diri sebagai manusia yang seutuhnya. Ilmu pengetahuan dan wawasan yang lebih luas dapat diperoleh melalui dunia pendidikan dan pengalaman, untuk memperoleh ilmu harus mempersiapkan diri sejak dini bila perlu anak masih dalam kandungan, semenjak dari kandungan anak sudah diajarkan menyanyi, mengaji bahkan sampai diperkenalkan nama keluarga. melalui hal ini kehadiran anak ketika berada dalam rahim harus dijaga dan diperhatikan baik gizi maupun posisi. Indonesia sekarang masih mencari solusi bagaimana cara untuk mengatasi permasalahan anak baik dari awal kandungan sampai umur dua tahun karena banyak yang dengar dari unsure pemerintahan baik tenaga medis maupun pemerintahan provinsi untuk mengentaskan stanting dan gizi buruk karena permaslahan ini merupakan permasalahan yang sudah menasional. Permasalahan ini bisa menghambat pertumbuhan anak baik dari segi fisik maupun kecerdasan otak pada anak. Setelah anak berumur empat tahun anak mulai melatih motorik anak agar pertumbuhan anak terus berkembang dengan baik (Fitriani, 2018; Hafidz, 2018).

Menurut Ghazali bermain mempengaruhi perkembangan dan pertumbuhan anak baik secara fisik-motorik maupun secara psikologi atau kejiwaannya serta perkembangan intelegensinya (Purnamasari \& Nurhayati, 2019; Saputro \& Talan, 2017). Pernyataan tersebut dapat asumsikan bahwa melalui permainan bisa kita melatih fisik anak untuk meningkatkan perkembangannya, dari sini peneliti akan menguji bentuk latihan motorik kasar halus melalui introduction to cooperative game. Anak usia dini sangat senang dengan bermain karena masa anak-anak senang dengan bermain sehingga peneliti akan melatih motorik kasar halus anak usia dini melalui permainan. Bermain merupakan hal yang tidak tersetruktur dalam gerakan tetapi dapat meningkatkan kebugaran karena pada saat bermain anak tidak akan menyadari bahwa anak sedang melakukan latihan kebugaran, apabila sifat permainannya berhubungan dengan gerak. (Chairilsyah, 2019; Hasanah, 2016; Novitasari et al., 2019)

Bermain dapat memenuhi kebutuhan anak untuk secara aktif terlibat dengan lingkungan, untuk bermain dan bekerja dalam menghasilkan suatu karya, serta untuk memenuhi tugas perkembangan kognitif lainnya. Selama bermain, anak menerima pengalaman baru, memanipulasi bahan dan alat, berinteraksi dengan orang lain dan mulai merasakan dunia mereka. Bermain menyediakan kerangka kerja pada anak untuk mengembangkan pemahaman tentang diri mereka sendiri, orang lain dan lingkungan Gerak berperan penting dalam pertumbuhan dan perkembangan fisik, sehingga gerakan yang bisa membentuk motorik harus diperkenalkan sejak dini kepada anak usia dini. Pertumbuhan dan perkembangan dapat dibentuk melalui gerak, permainan yang lebih variatif dengan gerakan maka akan lebih cepat dalam membentuk motorik pada anak. Penguasaan yang lebih variatif pada anak dalam bergerak sejak dini merupakan bekal utama untuk membantu menjadikan manusia yang terampil dan cekatan dalam bergerak, sehingga tercapailah kehidupan yang lebih baik dimasa yang akan datang karena memiliki motorik yang baik (Elfiadi, 2016; Hewi \& Asnawati, 2021; Rini \& Fatmawati, 2017).

Model Latihan Motorik (Hariadi, Suryansah, Sururuddin, Hadi) 


\section{METODE PENELITIAN}

Jenis Penelitian ini merupakan penelitian Deskriptif Kuantitatif. Penelitian ini Bertujuan untuk mendeskripsikan seberapa jauh pembelajaran akuatik dalam Introduction To Cooperative Game Pada Anak Usia Dini dapat mengembangkan atau membentuk motorik halus anak. Adapun instrument yang akan digunakan untuk melakukan kegiatan penelitian ini yang dijadikan acuan untuk mendapatkan data. Penelitian ini akan memfokuskan dari 10 anak yang memiliki umur 4-5 tahun. Pengumpulan data dilakukan untuk mengukur sejauhmana keberhasilan dari penelitian yang dilakukan. Teknik pengumpulan data yang digunakan pada penelitian ini adalah wawancara, observasi dokumentasi, dan angket. Analisis data yang akan digunakan menggunkan kuantitaif deskriptif(Purnamasari \& Nurhayati, 2019; Sugiyono, 2016).

\section{HASIL DAN PEMBAHASAN}

Hasil yang lakukan oleh peneliti pada R.A. Al-Irsyad Nw Kuang Derek Rumbuk yang memiliki siswa sebanyak 10 siswa pada kelas B. Berikut tahapan yang akan dilaksanakan Analisis kebutuhan dilakukan untuk menganalisis keadaan atau kondisi baik dari sarana dan prasarana yang akan digunakan untuk melakukan pembelajaran akuatik dengan introduction cooverative game pada anak usia dini. Tahap ini peneliti mulai merancang bagaimana sitem permainan yang akan dilaksanakan dalam pembelajaran akuatik. Pertama peneliti menentukan kelompok dari peserta yakni anak usia dini, setelah pembagian kelompok kemudian peserta diberikan pengarahan yang didampingi oleh gurunya agar ketika peneliti menyampaikan masalah teknis pelaksanaan nanti akan dibantu oleh gurunya. Adapun Sarana dan prasaran yang dibutuhkan adalah Kolam renang anak, bola plastic kecil, stropom, keranjang, dan lipri.

Tahap Pelaksanaan
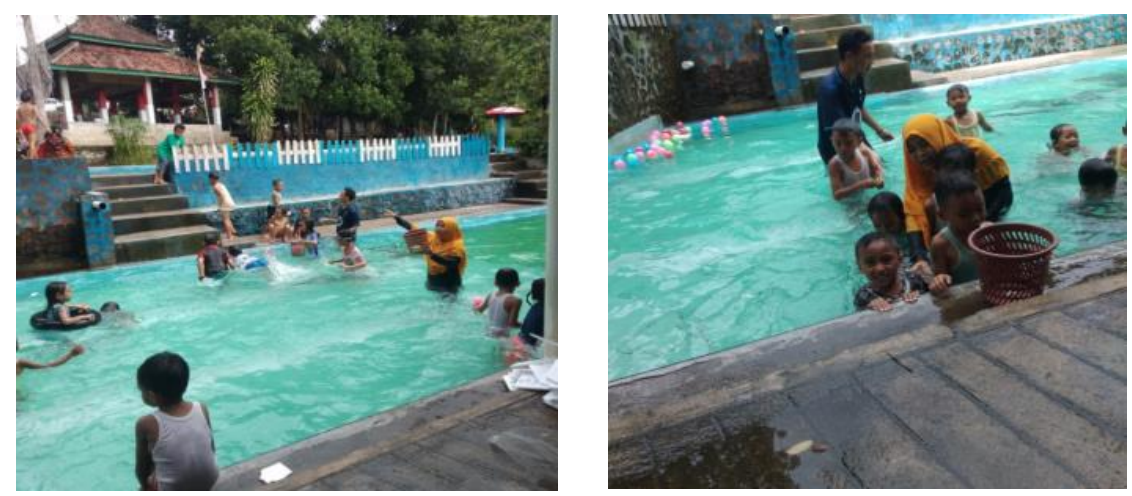

Gambar 1: Melempar Bola plastic kedalam Keranjang

Sumber Pribadi: Bermain Melempar bola plastic ke dalam keranjang Terlebih dahulu anak diberikan pengarahan kemudian anak disiapkan diatur jarak melempar dengan keranjang yang sudah disiapkan dipingir kolam, jarak lemparan yang akan dilakukan sepajang 3 meter dengan banyak lemparan sepuluh kali lemparan. yang pertama kali melakukan lemparan yakni kelompok A masing- masing kelompok berjumlah lima orang. Satu peserta dikasi kesempatan sebanyak dua kali lemparan. Kelompok B juga memiliki anggota sebanyak lima orang dengan aturan yang sama dan jumlah peserta, jarak 
lemparan, dan kesempatan sama dengan kelompok A. Setelah melakukan lemparan antara kelompok A dan kelompok B peneliti mendapatkan hasil dari kelompok A lemparan bola plastic yang masuk ke keranjang sebanyak 10 Bola dari lima peserta sedangkan dari kelompok B sebanyak 9 bola yang mampu dimasukkan ke keranjang pada lemparan pertama. setelah lemparan yang ke dua kelompok A dapat memasukkan 14 bola ke dalam keranjang sedangkan kelompok B dapat memasukkan 20 ke dalam keranjang. Hasil persentase saat lemparan pertama kelompok A hanya mampu memasukkan bola plastic ke dalam keranjang sebanyak $5 \%$ dan kelompok B sebanyak 4.5\%. Kemudian pada lemparan ke dua kelompok A sebanyak $7 \%$ dan Kelompok B sebanyak $10 \%$.
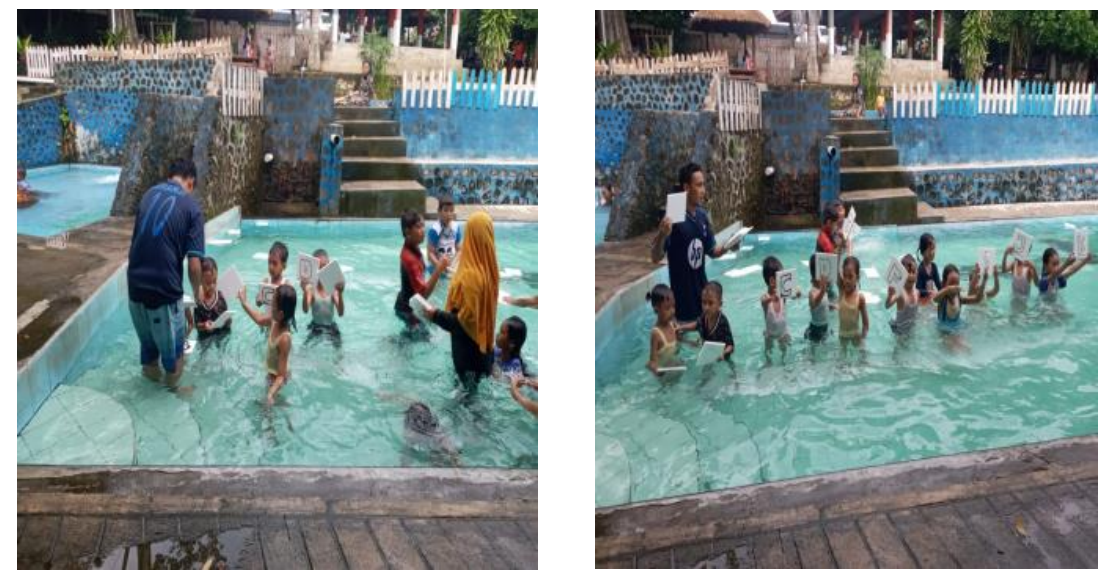

Gambar 2: Menggunakan Media Steropom yang ada Abjad Untuk Belajar Mengenal Huruf

Bermain menggunakan media Air dan steropom untuk mengenal huruf Dalam permainan ini ada beberapa yang harus dipersiapkan diantaranya: Kolam Renang, Steropom, Spidol Permanen, dan Pluid. Kemudian perserta dibagi menjadi dua bagian yakni kelompok A dan kelompok B, setelah pembagian kelompok lalu peserta diberikan pengarahan masalah teknis pelaksanaan. Caranya adalah Stropom yang sudah di tulis dengan huruf Abjad A sampai $\mathrm{Z}$ kemudian dilepas di kolam renang dibiarkan mengambang diatas permukaan air, selanjutnya peserta dibariskan sesuai dengan kelompok masing-masing kemudian guru memberikan aba-aba untuk bersiap misalnya guru menyuruh anak untuk mencari huruf yang di keluarkan atau yang dipegang oleh guru setelah misalkan dengan kata "Bisa" maka peserta mengejar atau mencari stropom yang dilepas diatas permukaan air dengan mencari huruf sesuai degan kata yang diperintahkan oleh guru. Setelah peserta mendapatkan huruf maka peserta disuruh kembali ke kelompok masing-masing dengan mengangkat huruf yang diambil. Kemudian guru mengintruksikan kepada peserta untuk menyatukan huruf sesuai dengan kata yang diperintahkan ibu guru dan semua peserta harus menyebut huruf yang dipegang kemudian selanjutnya peserta mengeja setelah huruf disatukan sesuai dengan perintah guru. Setelah dilakukan kesempatan pertama masih banyak dari peserta yang salah menyebut nama huruf yang dipegang, pada kelompok A ada 3 peserta yang salah menyebut nama huruf sedangkan di kelompok B sebanyak 4 orang. Kemudaian peneliti dan guru memberikan pengarahan 
kepada peserta tentang pengenalan huruf dan bentuk dari huruf, hal yang pertama dilakukan stropom kembali dibiarkan berserakan diatas permukaan air kemudian peserta disiapkan sesuai dengan kelompok masing-masing seteal itu, peserta disuruh satu persatu untuk mencari huruf yang diinstruksikan oleh ibu guru dan peneliti misalkan ibu guru menyuruh peserta pertama dikelompok A mencari huruf "C" peserta tersebut mencari huruf " $\mathrm{C}$ " dan mengangkat huruf tersebut. Ketika semua peserta sudah mengenal rupa dan bentuk huruf selanjutnya peneliti dan guru mengulangi kembali dari permainan tersebut yakni dengan memberikan instruksi yang sama. Guru memberikan mengangkat huruf dengan tulisan kata kemudian peserta berlari mencari huruf yang dibuat dari stropom bersama kelompok masing - masing setelah dua kelompok mencari huruf kemudian kembali keposisi yang sudah ditentukan dan disiapkan. Pada kesempatan kedua kelompok A disuruh untuk mengangkat dan menyebut huruf yang dipegang, semua peserta mengenal huruf dan bisa menyebut huruf yang dipegang hal yang sama juga dilakukan pada kelompok B. Namun pada kelompok B hanya satu peserta yang belum bisa menyebut huruf namun sudah mengenal huruf yang ditunjukkan. Kalau dipersentasekan dari kesempatan pertama kelompok A yang sudah mengenal huruf sebanyak $20 \%$ dan kelompok B sebanyak 10\% sedangkan yang belum bisa mengenal huruf dari kelompok A sebanyak 30\% dan kelompok B sebanyak 40\%. Setelah diberikan kesempatan kedua kelompok A yang sudah bisa menyebut dan mengenal angka sebanyak 100\% dan pada kelompok B Sebanyak 90\%.

Dari apa yang dilakukan oleh peneliti dan guru pada saat penelitian, kegiatan yang dilakukan sangat menyenangkan untuk dilakukan oleh peserta karena sambil bermain banyak hal yang diperoleh oleh peserta disamping bisa berenang dan berlari dalam air. Ketika siswa berenang dan berlari maka motorik yang dibentuk yakni motorik kasar akan tetapi peserta tidak menyadari hal tersebut karena dilakukan dengan dasar bermain secara berkelompok. kemudian hasil persentase yang dilakuakn pada saat bermain dari melempar bola ke dalam keranjang dan mencari huruf yang sesuai dengan perintah guru maka anak disini sudah dilatih dan dibentuk motik halusnya. Sehingga dalam penelitian ini sangat signifikan untuk dilakukan terhadap anak usia dini dalam mengembangkan dan membentuk motorik halus.Pada Saat dilakukan uji coba pertama dari 10 peserta yang dibagi dalam dua kelompok peserta masih melempar bola tidak dalam posisi konsentrasi sehinga memiliki hasil yang rata- rata peserta tidak memasuki keranjang. Setelah uji coba pertama selesai kemudian peserta masuk ke uji coba ke dua, dari 10 peserta yang dibagi menjadi dua kelompok yang diberikan kesempatan 20 kali lemparan rata-rata dapat memasukkan bola ke dalam keranjang yakni di kelompok A Dapat memasukkan 14 bola dari 20 bola sedangkan di kelompok B dari 20 bola dapat memasukkan 20 bola ke dalam keranjang, sehingga melalui permainan akuatik introduction to cooperative game anak usia dini dapat membentuk motoric halus anak.

\section{KESIMPULAN}

Melalui pembelajaran akuatik dengan introduction cooveratif game pada penelitian ini sangat bisa dijadikan pembelajaran untuk membentuk motorik halus anak pada usia dini. kemudian hasil persentase yang sudah dilakukan pada saat bermain dari 
melempar bola ke dalam keranjang dan mencari huruf yang sesuai dengan perintah guru dan disebut kemudian disatukan untuk di eja maka anak disini sudah dilatih dan dibentuk motorik halusnya. Sehingga dalam penelitian ini sangat signifikan untuk dilakukan terhadap anak usia dini dalam mengembangkan dan membentuk motorik halus. Saat dilakukan uji coba pertama dari 10 peserta yang dibagi dalam dua kelompok peserta masih melempar bola tidak dalam posisi konsentrasi sehinga memiliki hasil yang rata- rata peserta tidak memasuki keranjang. Setelah uji coba pertama selesai kemudian peserta masuk ke uji coba ke dua, dari 10 peserta yang dibagi menjadi dua kelompok yang diberikan kesempatan 20 kali lemparan rata-rata dapat memasukkan bola ke dalam keranjang yakni di kelompok A Dapat memasukkan 14 bola dari 20 bola sedangkan di kelompok B dari 20 bola dapat memasukkan 20 bola ke dalam keranjang, sehingga melalui permainan akuatik introduction to cooperative game anak usia dini dapat membentuk motoric halus anak.

\section{DAFTAR PUSTAKA}

Arifiyanti, N., Fitriana, R., Kusmiyati, R., Sari, N. K., \& Usriyah, S. (2019). Motorik Kasar Anak Usia Dini. Al Athfal: Jurnal Kajian Perkembangan Anak dan Manajemen Pendidikan Usia Dini, 2(1), 36-44.

Chairilsyah, D. (2019). Web-Based Application to Measure Motoric Development of Early Childhood. JPUD - Jurnal Pendidikan Usia Dini, 13(1), 1-14. https://doi.org/10.21009/10.21009/jpud.131.01

Elfiadi. (2016). Bermain Dan Permainan Bagi Anak Usia Dini. Jurnal Itqan, VII(1), 5160.

Fitriani, R. (2018). Perkembangan Fisik Motorik Anak Usia Dini. Jurnal Golden Age Hamzanwadi University, 3(1), 25-34. http://nurul24.blogspot.co.id/2012/01/perkembangan-fisik-dan-motorik-anak.html

Hafidz, I. P. (2018). TERHADAP PERKEMBANGAN SOSIAL ANAK KELOMPOK B2 DI PAUD SITI KHADIJAH TAHUN 2018.

Hasanah, U. (2016). Pengembangan Kemampuan Fisik Motorik Melalui Permainan Tradisional Bagi Anak Usia Dini. Jurnal Pendidikan Anak, 5(1), 717-733. https://doi.org/10.21831/jpa.v5i1.12368

Hewi, L., \& Asnawati, L. (2021). Strategi Pendidik Anak Usia Dini Era Covid-19 dalam Menumbuhkan Kemampuan Berfikir Logis. Jurnal Obsesi : Jurnal Pendidikan Anak Usia Dini, 5(1), 158-167. https://doi.org/10.31004/obsesi.v5i1.530

Ilhami, B. S., \& Khaironi, M. (2018). Pelaksanaan Joyfull Learning Berbasis Permainan Tradisional Sasak Untuk Meningkatkan Motorik Kasar Anak Usia 5-6 Tahun. Jurnal Golden Age, 2(02), 59-65.

Novitasari, R., Nasirun, M., \& D., D. (2019). Meningkatkan Kemampuan Motorik Kasar Anak Melalui Bermain Dengan Media Hulahoop Pada Anak Kelompok B Paud AlSyafaqoh Kabupaten Rejang Lebong. Jurnal Ilmiah POTENSIA, 4(1), 6-12. https://doi.org/10.33369/jip.4.1.6-12 
Purnamasari, A., \& Nurhayati, N. (2019). Faktor-Faktor Yang Mempengaruhi Kemampuan Kognitif Anak Usia 5-6 Tahun Di Taman Kanak-Kanak. KINDERGARTEN: Journal of Islamic Early Childhood Education, 1(2), 124. https://doi.org/10.24014/kjiece.v1i2.6657

Ramdani, L. A., \& Azizah, N. (2019). Permainan Outbound untuk Perkembangan Motorik Kasar Anak Usia Dini. Jurnal Obsesi: Jurnal Pendidikan Anak Usia Dini, 4(1), 482490.

Rini, R., \& Fatmawati, N. (n.d.). Permainan Tradisional Meningkatkan Kemampuan Motorik Kasar Anak di PAUD Cahaya Kartini Bandar Lampung. 1.

Saputro, H., \& Talan, Y. O. (2017). Pengaruh Lingkungan Keluarga Terhadap Perkembangan Psikososial Pada Anak Prasekolah. Journal Of Nursing Practice, 1(1), 1-8. https://doi.org/10.30994/jnp.v1i1.16

Saripudin, A. (2019). Analisis Tumbuh Kembang Anak Ditinjau Dari Aspek Perkembangan Motorik Kasar Anak Usia Dini. Equalita: Jurnal Pusat Studi Gender dan Anak, 1(1), 114-130.

Sugiyono. (2016). Metodologi Penelitian Kuantitatif, Kualitatif, dan R\&D. In $C V$ Alfabeta. https://doi.org/https://doi.org/10.3929/ethz-b-000238666

Sulistyaningtyas, R. E., \& Fauziah, P. Y. (2019). Pengembangan buku panduan permainan tradisional untuk meningkatkan kemampuan motorik kasar anak usia 5-6 tahun. JPPM (Jurnal Pendidikan dan Pemberdayaan Masyarakat), 6(1), 50-58. 